\title{
Environmental Management Meeting the Requirements for Sustainable Development in Vietnam
}

\author{
Phung Van Hien ${ }^{1}$ \\ ${ }^{1}$ National Academy of Public Administration, Hanoi, Vietnam. \\ Correspondence: Phung Van Hien, National Academy of Public Administration (NaPa), No 77 Nguyen Chi \\ Thanh, Dong Da district, Hanoi, Vietnam. Tel: 84-024-3734-9782; 84-8-8889-6868. E-mail: \\ phunghiennapa@gmail.com
}

$\begin{array}{lc}\text { Received: February 24, } 2021 & \text { Accepted: March 23, } 2021 \quad \text { Online Published: May 5, } 2021 \\ \text { doi:10.5539/par.v10n2p7 } & \text { URL: http://dx.doi.org/10.5539/par.v10n2p7 }\end{array}$

\section{Summary}

The State uses legal tools to manage the environment, because the environment plays a particularly important role in the survival and development of the ecosystem and humanity.

Keywords: environment, natural resources and environment, environmental management, environmental protection, climate change, waste

\section{Overview of the Environment}

The environment has an impact on the socio-economic development of each country, including Vietnam. On the positive side, socio-economic development in the market economy improves the natural environment, creating funding for that improvement. However, the downside of the market economy is the clear differentiation, if the economy develops massively, without a plan, it can cause negative impacts on the environment, such as the degradation of natural resources, causing climate change ... When the environment is degraded, it can also cause disasters, natural disasters, seriously threaten socio-economic activities and the quality of human life.

Environment includes natural and man-made elements that are closely related to each other, surrounding people, affecting the life, economy, society, existence and development of humans and organisms. and natural. (Law on Environment Protection of Vietnam 2020).

Environmental protection activities are activities to prevent and limit negative impacts on the environment; respond to environmental incidents; overcoming environmental pollution and degradation, improving environmental quality; rationally use natural resources, biodiversity and respond to climate change. The environment is composed of earth, water, air, organism, sound, light, and other physical and

Each country must use its tools to have an organized impact on the target audience to plan and operate through relevant agencies, units, businesses and individuals in each sector so that the environment. must ensure technical standards to serve human life and socio-economic development of the country.

Sustainable management and environmental protection, the need to adapt to climate change, the development process meets the current needs without compromising the ability of generations to meet that need. future on the basis of a close and harmonious combination between economic growth, ensuring social progress and environmental protection.

\subsection{Organizing Environmental Management Apparatus}

Environment is a common global issue. International environmental organizations are established. In Vietnam, there are environmental management apparatuses from the central to grassroots levels (Diagrams 01, 02). 


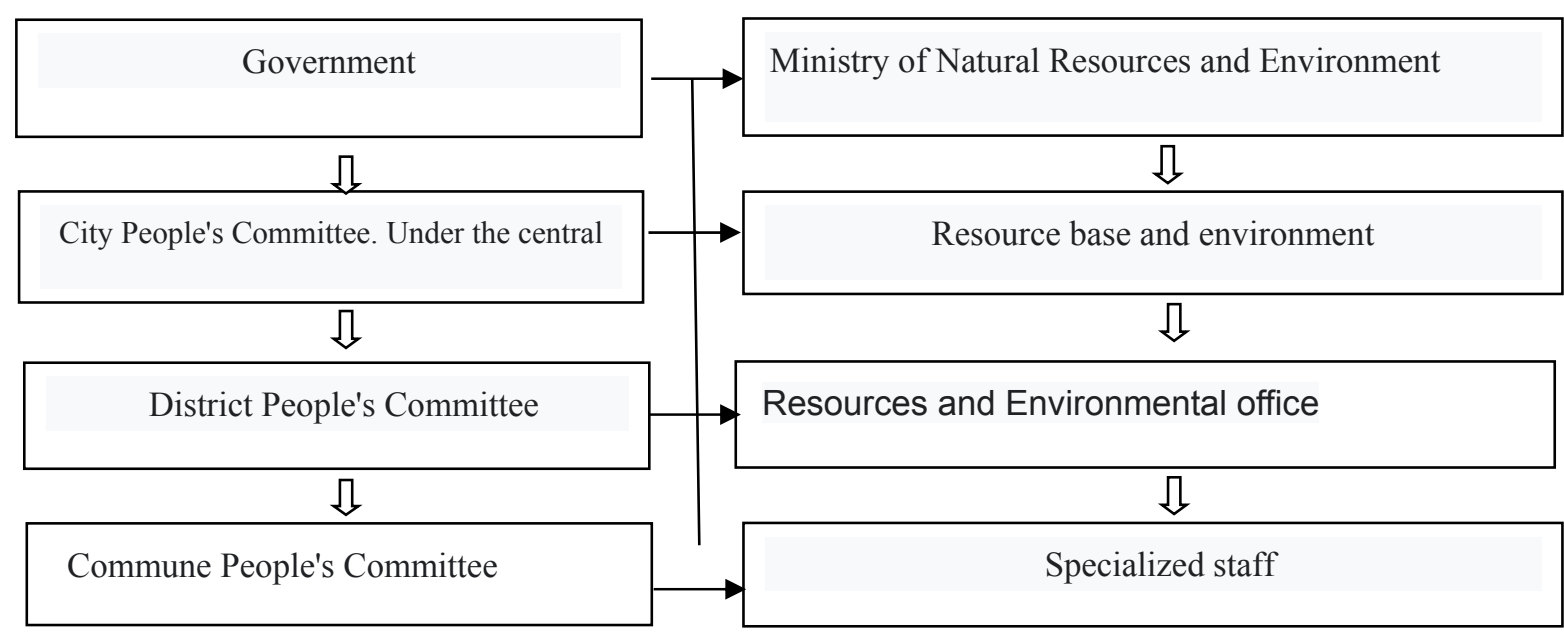

Chart 1. System of State management agencies on environment in Vietnam

Source: Vietnam Environment Administration (Ministry of Natural Resources and Environment)

(Ministry of Science and Technology: nsuring environmental protection requirements in the national strategy, master plan and socio-economic development plan.)
(Ministry of Construction: implementation of the law on environmental protection in the construction of water supply, drainage, solid waste and wastewater treatment in urban areas), ...
$\Omega$

(Ministry of Agriculture and Rural Development: implementing the law on environmental protection in the production, import, and use of chemicals and plant protection drugs nationwide).

约

(The Ministry of Industry and Trade: to deal with industrial establishments causing serious environmental pollution under their authority to manage and develop the environmental industry.

\section{Diagram 2. Relationship between Vietnamese environmental regulatory agencies}

Ministry of Natural Resources and Environment Source

\subsection{International Cooperation on the Environment}

Cooperation with Singapore: In the fields; climate change mitigation and adaptation; pollution control, air quality management, solid waste, hazardous waste, noise management and cooperation on regional environmental issues of mutual concern, exchange information, share experiences about expertise is the strength of each party, promoting cooperation in implementing expert exchange programs; attend conferences, seminars, study, activities on issues related to environment and water resources, promote technology transfer on environment and water resources, 2018 (People's Daily 3 years 2018).

Cooperation with Switzerland: Sustainable development in the field of Natural Resources and Environment in April 2018. Switzerland will invest in projects to assist Vietnam in developing a national adaptation plan, implementing a program program. response to climate change and green growth. At the same time, it helps Vietnam strengthen capacity to participate in effective management of marine waste and pollution treatment; cooperation in training, education and experience sharing in the field of Natural Resources and Environment; as 
well as supporting Vietnam to effectively implement international conventions, to deeply participate in multilateral cooperation mechanisms in the field of Natural Resources and Environment. (Viet Nam Minister of Natural Resources and Environment and Swiss Minister of Natural Resources and Environment dated April 4, 2018)

Joint Declaration of the Cambodia - Laos - Vietnam Development Triangle Area Summit in April 2018. Including environmental issues reaffirmed its commitment to environmental protection, rational use and management Sustainable efficiency of natural resources, including water resources and forests. We encourage government departments and other stakeholders to continue to integrate sustainability into the three countries' cooperation programs. Encourage further increased information exchange between the three countries through information sharing and early warning systems for floods, droughts, natural disasters and transboundary pollution (Tam Cambodia - Laos - Vietnam development for the 10th time on March 31, 2018).

Cooperation with Korea, in the fields of environment, land, metrology and mapping, sea and islands, meteorology and hydrology, sponsored a number of Vietnamese officials, including Ministry of Natural Resources and Environment participating in research and training courses in Korea. For the multi-land field, building a multi-land database management system, can propose better solutions, learn models, experiences and technologies of other partners to improve efficiency. results of cooperation (Cooperation between the Ministry of Natural Resources and Environment of Vietnam and KOICA on April 20, 2018).

\subsection{Some studies on the Environment in Vietnam}

Author Nguyen the Chinh. Institute of Strategy and Policy on Natural Resources and Environment: Based on the perception of international experience in natural resource and environmental protection, with the previous view from the nineteenth century to the current one, the world has experiencing ups and downs in protecting natural resources and the environment, from which to draw valuable experiences for us. The following developed countries like Vietnam, if we can overcome the problems that the previous countries have encountered, and bring into play the good experiences they have succeeded, we will shorten the development gap, not only the increase. economic growth is high but also protects natural resources and the environment in line with the new trend of the twenty-first century of sustainable development.

Institute of Strategy and Policy on Natural Resources and Environment (UNEP translated document) (2011). Towards a green economy, a roadmap for sustainable development and poverty reduction. Synthesized report serving policy makers. Agricultural publisher.

Author Thanh Hoang, Environmental protection is protection of self and community health. Environment has long been the concern of all mankind and environmental issues, environmental protection at any time, each time of each country is also considered a very important task. All of the above mentioned issues have a great impact on people's lives (on life and health), Environment Magazine June 5, 2017. Author Ha Phuong, proactively protecting natural resources and the environment. Identifying targets to respond to climate change (climate change), proactive solutions to climate change; promote the protection of natural resources and the environment "that the Ministry of Natural Resources and Environment has just given opinion of the ministries. Saigon Liberation Newspaper January 30, 2013. Research on biotechnology to treat and reuse domestic waste sludge from concentrated wastewater treatment plants of industrial zones, pilot in the Southeast region, a ministerial-level topic by Assoc. Ton That Lang, Ho Chi Minh City National University is in charge, in 2016.

\subsection{Environmental Studies in Several Countries}

Firstly, prioritizing saving and efficiency as the core for building a comprehensive resource saving system, enhancing the important position of saving resources in economic development strategy. social, improve resource use efficiency, one more step strengthen guidance on policies for saving resources, make every effort to adjust and optimize industry structure, to exploit and disseminate resource-saving techniques, eliminate outdated technologies and equipment, strengthen the management of resource production, transportation and consumption phases. Second, taking the cyclical economic development, the economy that produces low carbon is the basic way to build the national economic system in the form of saving resources. Third, taking energy saving, water saving, material saving, land saving and natural resource use is the key to building the national economic system.

In the US, there is a re-examination of the mode of economic development to promote economic growth, increase employment, and adopt the strategy of "Re-industrialization". November 2009, President Obama introduced the US growth model to switch to a sustainable growth model. In the strategy of "Re-industrialization" for the next 10 years to develop new technologies, it is expected to invest $\$ 15,000,000$ to support new energy sources, encourage businesses to innovate technology, save money. energy, especially small and medium enterprises. Transport systems, especially for the planned green separator-planned highways, are required. Although the solution in the US follows the "Low 
Carbon Economy", but with that approach is also the content towards the development of "Green Economy". In some Western European countries and Japan, the development trend is also towards "Clean Economy", "Low Carbon Economy" and "Green Economy", these countries have gone through a long period of time. of the process of industrialization and also at the expense of resource degradation and environmental quality. Western Europe has worked hard to incorporate low carbon targets into the international regulatory system, with the introduction of the international certification standard for the "Carbon Footprint" that paved the way.

In Japan, the trend of carbon reduction is actively adopted by the Kyoto Protocol, thoroughly implementing the 3R strategy "Reduce, reuse and recycle" waste and save resources and protect the environment. The EU is expected to invest $€ 105$ billion by 2013 to develop a "clean economy". At the end of 2009, launched a new growth strategy, focusing on two new industries, the environment and energy sectors, the health sector, with investment in these two sectors expected to create a new equivalent market by 2020.1 million billion yen. Thanks to the industrialization process such as Korea, Singapore., Group of emerging countries, the development model from the beginning has focused on the environment and saving resources, so they have shortened the development gap. Only achieve economic goals but focus on the environment. Currently, these countries continue to develop in the trend of "Green Growth", "Low carbon economy" and towards a green economy. Theoretical and practical have shown that the world is undergoing new changes in development directions, especially after the financial crisis and economic recession from 2008 up to now, which is economic restructuring. economy, towards building a green economy.

\section{Methodology}

Methods of document analysis and secondary data analysis are the two methods we use in the research process. Compiled data from documents such as books, magazines, domestic and international studies related to state management of environment to meet the requirements of sustainable development in Vietnam. The documents focus on some main contents such as strategy, planning, environmental management and protection plan to promote the human role; principles of raising awareness of people and social communities as well as the role of state management agencies on environmental protection.

In addition, we also collect secondary data through the statistical yearbooks of the provincial statistical offices in Vietnam to clarify the current state of forest management to meet the requirements of sustainable development in Vietnam. Several reports from organizations such as the Ministry of Natural Resources and Environment, the local environmental management agency (Thua Thien Hue province Vietnam) are also important secondary documents for this study. In addition, we refer to legal documents such as the 2015 Vietnam Law on Environmental Protection and the 2020 Vietnam Law on Environmental Protection, which came into effect from January 1, 2022, including some that is applicable in 2021; Law on Marine and Island Natural Resources and Environment in 2015; Law on local government organization 2015; Vietnam Law on Forestry 2017...

Data is carefully collected and synthesized according to each specific content related to environmental management to meet the requirements of sustainable development in Vietnam in recent years. For data that is not clear, we try to search through different sources to clarify the research problem. When we have enough data, we sort it, sort it, and process it. For statistics, we synthesize into tables for easy comparison and assessment of environmental management to meet the requirements of sustainable development in Vietnam.

\section{Research Results}

Socio-economic development strategy in Vietnam for the period 2015 - 2025, continues to be built towards sustainable and comprehensive development in all 3 fields: economy, society and environment. Accordingly, the environmental expenditure group is set with the goal of sustainably maintaining natural resources, improving the quality of the living environment and minimizing pollution, negative impacts of natural disasters and climate change. However, over time the implementation of annual environmental indicators is still relatively low compared to the set target. Some indicators have fairly steady growth over the years such as rate of forest cover, rate of urban and rural population using clean and hygienic water, rate of urban solid waste collection ... With this increase, it is also difficult to achieve the set target. Not to mention, the indicators such as the proportion of IZs, EPZs and IZs that must have a centralized wastewater treatment system have not been met, the reported data shows that the number is much lower than the set target. Although there have been adjustments compared to the previous period and quite close to the actual requirements, the implementation still faces many difficulties and shortcomings.

In 2020, Vietnam's Law on Environmental Protection is issued, addressing the current hot issues in environmental protection such as responding to climate change, promoting green economic growth, building environmental planning. school. Compared with the previous period, the system of legal documents on the environment has been 
more concretized. Scientific and technological research activities have continued to be promoted, with many programs and topics at the state and ministerial level. deployed. Communication activities and community awareness raising are increasingly diversified. International cooperation has also attracted many environmental investment projects. However, besides the results achieved, the environmental management still faces some difficulties and shortcomings.

Specific analysis and assessment of the current state of the environment and environmental management in the period 2015-2020 are the basis for identifying environmental challenges, which are: pollution problems and environmental incidents. It continues to increase in many regions. Those are positive changes in awareness, awareness of law observance of the community, summarizing the national environmental status report for the period 2015-2020 and enterprises.

\subsection{Air Environment}

For the air environment in urban areas, the pollution pressure is mainly caused by transportation activities, construction, from inner-city industrial establishments, cooking activities, and residential activities. waste treatment process and external pollution sources. Air pollution due to dust remains the most prominent problem in urban areas. dust concentration in the urban air changes over the months of the year, according to seasonal changes, clearly shown in the North; The Southern region has a significant difference between the dry season and the rainy season. Dust concentration changes according to the rules of the day, especially near the traffic axis.

\subsection{Water Environment:}

The water environment in rivers and lakes in urban areas is under great pressure from sources of waste from people's daily activities and economic development activities. The percentage of wastewater treated is still quite low, which has a great impact on the quality status of rivers, urban lakes. In many urban areas, canals, ditches and lakes in the inner city have become places to store domestic wastewater, production wastewater, typically in Hanoi, HCMC. Ho Chi Minh. Surface water pollution in the inner city area occurs not only in big cities but also in small cities. Most urban underground water quality is still relatively good. However, in some urban areas and big cities, it is noted that underground water has been polluted. Typically, there are pollution of Ammonium, heavy metals $(\mathrm{Mn}, \mathrm{A}, \mathrm{Pb})$ in some areas of the Northern Delta; Salinity problem in some areas in the Central Coast, downstream of Dong Nai river, and in the coastal provinces of the Mekong Delta.

Coastal water in some coastal urban areas has had pollution of organic matter, TSS, mineral oil such as Quang Ninh, Da Nang ... Especially, the development of coastal economic zones in The near-full time has led to the risk of environmental pollution and incidents due to poor management and management of waste.

\subsection{Earth Environment}

The increase in urban land fund in recent years has contributed to the formation of an urban network system which is reasonably distributed in all regions of the country, promoting industrialization and modernization. However, the proportion of land for infrastructure construction is low (accounting for about 29.78\%), many urban areas only account for about $10-15 \%$. Most of the land area is for housing projects and offices. In addition, the area of land for greenery land, water surface (pond, lake), playground land and other public works is still insufficient, not meeting the requirements of sustainable urban development. firm. The soil environment in urban areas is at risk of pollution due to impacts from domestic wastewater, industrial, construction, domestic and landfills, especially from big cities like Hanoi, HCMC. Ho Chi Minh City, Hai Phong, and Da Nang.

\subsection{Environment from Solid Waste}

Solid waste generation and treatment has remained a prominent environmental issue for many years. According to statistics, the amount of domestic solid waste generated in urban areas is about 38,000 tons / day with an average increase of $12 \%$ per year. Urban domestic solid waste has an organic rate of about $54-77 \%$, recyclable waste (plastic and metal components) accounts for about 8-18\%. Hazardous waste (HW) also mixed with domestic waste brought to landfill is $0.02-0.82 \%$. Medical solid waste generated is 600 tons / day with an increase of about $7.6 \%$ per year. As for industrial solid waste in urban areas, there are no specific statistics, but estimated volume of industrial solid waste generated in urban areas is quite high, focusing on mechanical, textile and leather industries. shoes and food. It is estimated that the amount of HW in industrial solid waste accounts for about $20-30 \%$.

The work of solid waste classification, collection and treatment has achieved certain results. The rate of domestic solid waste collection and treatment averaged about $85 \%$ in 2014 and increased to $85.3 \%$ in 2015 . The popular technology to treat domestic solid waste is landfilling, composting and burning. In urban areas, the rate of domestic solid waste directly filled by children is about $34 \%$, the rate of domestic solid waste recycled in treatment 
facilities is about $42 \%$ and the remaining solid waste is waste of the treatment process. $24 \%$ of those that are buried are buried. Most of urban domestic solid waste has not been classified at source.

\subsection{Urban Environment}

The growth of economic sectors in urban areas such as construction, industry, transportation, healthcare, trade-services as well as energy use and consumption has been creating a lot of pressure. with MT in urban areas. The economic growth rate in urban areas is 1.5-2 times higher than that of the whole country, of which industries, trade, services and tourism in big cities account for a relatively high rate in the total production structure. domestic products. New construction, urban renovation and upgrading generate a large amount of dust in the environment.

Urban environmental management has been paid attention; policies and legal regulations on urban environmental protection have been completed. Many projects and programs to improve environmental quality and overcome pollution have been implemented. However, there are still limitations and challenges in the planning, infrastructure construction and pollution control, especially in big cities. In which, a number of urban environmental problems are emerging such as: dust pollution continues to be maintained at a high level; water pollution in rivers, lakes, canals in the inner city and inner city is still complicated, the problem of inundation in urban areas is increasing; groundwater level reduction in delta urban areas and saline intrusion in coastal urban areas are becoming common; Percentage of urban solid waste is treated in accordance with techniques, environmental sanitation is low, treatment technology is outdated and not suitable with the actual conditions.

\subsection{Marine Environment}

Currently, due to the development, urban expansion and the increase in mechanical population, the construction of harbors and factories; Tourism and aquaculture activities are not only a threat, but environmental pollution has broken many landscapes and biodiversity (biodiversity) in many marine areas in our country, causing many deaths. Bacteria, the construction of new ports in the Gulf, could lead to an increase in sea traffic in the region. The cause of this pollution is economic development activities, especially from industrial, agricultural and shipping waste sources. The coastal area is also the place that suffers from waste pressure from nearly $60 \%$ of the total population, about $50 \%$ of the major cities of the country. Most of the wastes from daily life and industrial zones are discharged directly into the sea, a part of solid wastes in rivers and seas cause coastal environmental pollution.

Pollution sources carried by rivers and streams to the sea include oil and oil products, wastewater, agricultural fertilizers, pesticides, industrial wastes, radioactive wastes and many other pollutants. Every year, the solid wastes dumped into the sea around the world are about 50 million tons, dirt, sand, rubbish, construction scrap, radioactive substances. Some of these wastes will settle in coastal waters. Several other substances are broken down and spread throughout the seawater body. Although the issue of collection and treatment of waste in coastal areas has been concerned by all levels, sectors and local authorities, it has not been properly invested. All waste sources from rivers, canals, lakes, residential areas ... are discharged into the sea.

Currently, Vietnam's sea is facing high risks of pollution in the future, with great challenges that require effective and correct investment measures. The immediate reason is that it is affected by climate change, in addition to economic and major difficulties and inconsistent policies affecting the resolution of sudden natural incidents. And an important cause is the pollution of rivers from the mainland. Law on Environmental Protection 2014 and Law on Environment Protection 2020, Law on Marine and Island Environment 2015, Maritime Code 2015, Law on Petroleum 1993, amended and supplemented in 2008, Law on Tourism 2005, Law on Fisheries year 2017 and the guiding documents, regulations on KSONMTB all stipulate that, based on the principles of environmental protection, prevention is key.

Marine economic development contributes largely to the economic development of Vietnam. However, according to the law, the treatment of marine EP is the responsibility of the waste source owners, state agencies, and competent entities. In addition to overcoming pollution and restoring the current state of marine environment, entities that violate environmental laws may be liable for legal responsibility. Depending on the severity of the law violation, the subject may have different legal responsibilities such as administrative, criminal, civil, and disciplinary responsibilities

criminal, civil, discipline. For the responsibility to compensate for damages related to natural resources and environment has been specified in Decree No. 03/2015 / ND-CP of the Government. The Decree has determined that the responsibility for claiming this damage belongs to the competent state agency, but it is still ineffective. As for the damage to health, life, property and legitimate interests of individuals and organizations as defined in the Civil Code 2015, the Law on Environmental Protection 2014 and 2020, however, up to now It can be seen that no environmental damage claims have been resolved in court; The current law also makes it difficult for individuals 
and organizations in the process of claiming damages because it is difficult to prove a causal relationship between the EP and damage occurring.

The current Law on Environment specifies the responsibilities from the Government to the People's Committees at all levels as well as the responsibilities of the competent state agencies in the KSONMTB. However, in recent years, the marine environment in Vietnam still occurs with pollution. This fact shows that the efficiency of state management on the marine environment is very low. Meanwhile, the monitoring mechanism from the State as well as the community, the media and the press on KSONMTB activities has not been effective.

\section{Factors Affecting Environmental Management}

\subsection{Objective Factors}

Every year, due to climate change and environmental change, storms, flash floods, and pipe floods have destroyed many special-use forests, protection forests, and production forests, causing great impacts and damages. resources. On the other hand, degrading and causing significant damage to infrastructure, especially seriously polluted environment, people's lives face many difficulties, must be overcome in a long time and need resources. great force. Therefore, the State management of natural resources and environment of functional agencies has encountered many obstacles.

In some countries with different economic development levels, the tendency to cause EP is different. Pollution due to excess: $20 \%$ of the world's population in rich countries currently use $80 \%$ of human resources and energy. Industrial production develops strongly, the activities of too many means of transportation have created a large amount of toxic waste into the environment (especially exhaust gas). Pollution due to poverty: Although accounting for $80 \%$ of the world's population, but using only $20 \%$ of the world's resources and energy, the poor in poor countries have the only way to exploit. natural resources (forests, minerals, land, ...) that cannot be recovered. Therefore, in order to solve the environmental problems, first of all, rich countries have a responsibility to help poor countries solve poverty.

\subsection{Subjective Factors}

Environmental protection policy, investment policy on environmental protection have not been attached to, synchronized with other (socio-economic) policies, there is no priority policy for investment in construction and infrastructure, human resource development. , sedentary farming, stabilizing and improving the lives of people in areas affected by nature causing EP.

Regarding climate change response, there are policy solutions to mobilize financial resources, improve legal policies as well as promote the role of science and technology in responding to climate change and environmental protection is still inadequate. This solution is based on the principle of "those who benefit from natural resources and the environment have to pay", "the people who cause environmental pollution have to pay costs for environmental treatment, remediation and improvement" in the direction of correctly and fully calculating costs. investment and payment. Financial source for environmental protection: is still limited, has not yet brought into play the strength of organizations and individuals that have the responsibility to join hands in environmental protection to protect themselves. Promote the development of renewable energy and new energy into a green economy in the future. There is an appropriate roadmap to reduce subsidies for fossil energy and soon to have subsidies for renewable energy.

Effective response to climate change is vital to Vietnam. In the face of enormous challenges, challenges and threats, there should be a system of policies and solutions that are synchronous, comprehensive, strong enough, to make a breakthrough to direct the entire Party, the entire people and the entire army to actively respond to

Objective, scientific, practice-based assessment updated with major trends of the times, with reference to the experiences of other countries, can judge the situation, results achieved, shortcomings, weaknesses causes and problems, and at the same time gives the main viewpoints, objectives, tasks and major solutions to invest in climate change response and promote environmental management and protection.

Responsibilities of local authorities: People's Committees at all levels confirm the environmental protection plan of the project, the plan of production, business and service in the area. However, the assignment of coordination in the management apparatus from the provincial to the communal level lacks synchronization, is not drastic in directing and operating, the propaganda is not frequent, some measures are not realistic. affect the management of environment.

Inspection and supervision organization of competent state agencies: According to the regulations on the organization of the State management apparatus on natural resources and environment, the inspection and 
supervision work has specialized units from the central to the relevant establishments. relations interwoven, assigned to coordinate according to tasks. This is the most important job in management. In the coming time, the task of environmental protection is very heavy, many accumulated environmental problems have not been resolved, the pressure on the environment is increasing, the risk of our country becoming an outdated technology waste dump, the existing EP cell production; Climate change is fast and complicated, poses many great challenges for environmental protection. To overcome the limitations, proactively prevent, prevent and minimize pollution, create a fundamental change in environmental protection.

Human is the factor causing influence in management: In the process of promoting economic growth, people have to take away from nature many of its body parts such as animals, plants, soil, minerals. quality .. it is in that process that people have changed the natural gender. Big or small changes in the natural environment are brought about by the economic growth process. For the purpose of economic development, that person has affected natural environment in a beneficial or harmful way. Economic growth on the basis of applying scientific and technological achievements to production has partly eliminated undesirable consequences caused by uncontrolled human influence. course. Moreover, economic growth will create a physical premise to handle environmental incidents, ensure a clean environment.

In the opposite direction, human impacts on nature without rules such as natural resource exploitation, excessive mineral exploitation will make the natural environment unbalance, increasingly poor, exhausted, the ecological balance will be is broken and will naturally "avenge" on people. Thus, between economic growth and natural environmental protection there is both unity and contradiction. That unity and contradiction are reflected in social production. Humans who do not stop producing one way or another get materials from nature.

The majority of people are still indifferent to environmental protection and preservation, in many cases, for profit purposes, the environmental factor is ignored, making environmental pollution more and more increasing such as domestic waste, pollution from craft villages, and use. Plant protection drugs in agricultural production are not in accordance with regulations, excess drugs ... If promoting the role of local residents with local authorities, it will minimize difficulties in state management of environmental protection.

In particular, the capacity of environmental managers is still superficial, not drastic, evasive, has not shown roles and tasks overlap from central to grassroots levels.

\subsection{Environmental Pollution in Industrial Clusters in Thua Thien Hue Province, Vietnam}

Along with the socio-economic growth in the province, in the past years, the issue of EP also tends to increase. The main reason is that the authorities at all levels have not really paid attention to their tasks (environmental protection); awareness of implementing law on environmental protection of a part of population, agencies, organizations, production and business units is not high; the system of legal normative documents is incomplete; Some of the violations are of sophistication, making it difficult for the management and the detection and handling according to regulations (Table 01).

\section{Industrial wastewater}

The wastewater composition of industrial complexes depends on the industries of the industrial complexes (Table 01). Wastewater composition of ICs mainly includes suspended substances, organic substances, nutrients and heavy metals. The results of analysis of water surface quality in industrial complexes show: BOD5 and COD concentrations in surface water in industrial complexes have many operating facilities with value exceeding the permitted limit. The concentration of suspended solids in surface water in 2 ICs with the most operating facilities has a value exceeding the permitted limit. Solids suspended in surface water at Thuy Phuong industrial cluster in the area near the inlet of Chau Son lake, the slot discharges into Chau Son lake from Nam Lang slot, the receiving canal in the concrete mixing station and in bald water Tri A (An Hoa IC) has the value exceeding the average limit by about 1.5 times the permitted limit according to QCVN 08-MT: 2015, value C, column B1 (Chart 01).

Analysis results show that the amount of grease in the lake behind Vinatex Huong Tra Garment Joint Stock Company (Tu Ha Industrial Zone), the water ditch in front of the plastic recycling facility (Bac An Gia IC), the water canal flowing through the industrial cluster An Hoa has values exceeding the permitted limit according to QCVN 08-MT: 2015 / BTNMT, C value, column B1 from 2 to 8 times. The oil and grease content in surface water at other locations did not exceed the permitted limits.

Through the above assessment, we show that the water quality of rivers, lakes, baldness and ditches passing through active ICs due to the contribution of organic matter, suspended solids, grease, nutrients and Microorganisms should be contaminated. In which, notably Chau Son lake, canal flowing through An Hoa 
industrial cluster, the lake behind Vinatex Huong Tra Garment Joint Stock Company, water ditch in front of the plastic recycling facility. In order to better water quality of rivers, lakes, baldness and ditches passing through industrial complexes, ICs need to be invested in synchronous infrastructure, especially concentrated WWTP to reduce the pressure from IC activities. to MT.

In general, groundwater quality is relatively stable. However, the reserves and the ability to meet the needs of economic sectors in the future are very limited. The water environment plays a particularly important role in the socio-economic development of the province in general and for the industrial production sectors in particular. Therefore, the increase of solutions to protect water resources in industrial complexes is an urgent requirement.

\section{Air environment}

The emissions generated by the facilities are mainly caused by two sources: the burning of fuel to fuel production and the leakage of pollutants from the production process. However, at present, major manufacturing facilities are only able to control emissions from fuel combustion. Air pollution from the production process is almost uncontrolled, spreading to the outside area, can have an impact on the health of people living near the affected area According to the monitoring results, the quality of the ambient air of many manufacturing facilities in the industrial complexes is basically good. Currently, the problem of air pollution is mainly caused by activities of facilities operating with outdated technology, causing pollution or having not invested in a waste gas treatment system before being released to the outside environment. At the industrial complexes, the current air pollution is mainly expressed through dust, $\mathrm{SO} 2, \mathrm{CO}, \mathrm{NO} 2$. In the scope of the report, only focus on assessing the characteristic indicators of total suspended dust, $\mathrm{SO} 2, \mathrm{CO}, \mathrm{NO} 2$, areas that are considered to be affected by emissions of production facilities in the industrial complex. Dust at locations near paper production facilities, electronics manufacturing facilities, fine arts carpentry, etc. is often worth exceeding the permitted limit while at other locations the value does not exceed the permitted limit according to QCVN. 05: 2013 / BTNMT.

General assessment: On the basis of the results of air quality monitoring, the air quality in industrial complexes in this period was relatively good. The environment in industrial complex areas has only been polluted with suspended dust in a number of places where industries such as paper production, electronics manufacturing establishments, rubbing, handicraft, ..., and the concentration of Common pollutants such as $(\mathrm{CO}, \mathrm{SO} 2, \mathrm{NO} 2)$ are all very low, not exceeding the permissible value according to current regulations.

At present, the industrial complexes in the area are still considered to be in poor performance, except for An Hoa, Thuy Phuong and $\mathrm{Tu} \mathrm{Ha}$ industrial complexes, so the level of air pollution across all industrial complexes is assessed to be. low, only causing local pollution, but when ICs are well-operated and developed but there is no good environmental management and handling mechanism, air pollution is unavoidable.

\section{Earth environment}

Soil pollution is considered as the discharge of impurities and pollutants into the soil environment. Soil pollution generated in industrial complexes is mainly due to: production activities of establishments in industrial complexes emit a large amount of industrial waste; Due to the living process of officers and employees in industrial complexes also generates a large amount of domestic waste.

In addition, the industrial complexes with metal recycling facilities will cause the land area in the area to be contaminated with heavy metals and if the exhaust gas in the air in the ICs is not properly treated, it will cause acid rain. Increases the chemical acidity process.

This has created a great pressure on the soil environment. Especially, if the waste is HW, if it is not properly treated, it will be a serious source of soil pollution.

Soil pollution will lose the ability to self-regulate the soil ecosystem, the soil becomes barren and unsuitable for plants, affecting other living organisms in the food web.

\section{Environment from solid waste}

Production activities in industrial complexes have generated a large amount of solid waste and hazardous wastes. The composition and volume of solid waste generated in each industrial cluster depends on the type of industrial investment, investment scale and capacity of the facility in the industrial complex (Table 04).

In the solid waste wall of industrial complexes, the percentage of hazardous wastes is usually $<20 \%$. Estimates of hazardous wastes generated by manufacturing industries and the number of workers in the manufacturing industry $(\mathrm{kg} /$ person / year) are presented in (Table 04).

Waste collection and treatment 
Because there is no solid waste gathering yard in the industrial complexes, the facilities in the industrial complex manage conventional solid wastes by signing contracts with the units with full functions of collection, transportation and treatment.

According to "Notes on solid waste management planning in Thua Thien Hue province to 2030, with a vision to 2050":

The amount of conventional industrial solid waste generated in Thua Thien Hue province is quite small compared to domestic waste, because most of these wastes are recycled. The remaining common industrial wastes are collected and transported to landfills by functional units. Organic wastes in service businesses will be reused for livestock. Although there is no investment in solid waste gathering yards in each industrial complex, most of the facilities are self-aware about solid waste collection and treatment such as: arranging garbage cans on site, classifying solid waste, and contracting with functional units of solid waste collection and gathering strictly according to regulations. In addition, a number of establishments have registered hazardous waste source owners at the Department of Natural Resources and Environment. Therefore, through the process of surveying people living near industrial complexes, there is no opinion on the solid waste situation in industrial complexes.

\subsection{Limitations Need to Be Overcome}

Firstly: the provisions of the law on environmental protection are inadequate and inconsistent with the reality; There is also an overlap and conflicts with other relevant specialized laws. But the reality shows that the specialized organization on environment, especially at district and commune levels, is still weak and has not met the requirements of decentralization in general and the appraisal and confirmation of environmental procedures and activities. Decentralized dynamic. Secondly: Although the specialized organization system, specializing in environmental protection has been established, there is a limitation in quantity and quality that has not met the requirements of the operation and development process.

Thirdly: Investment in environmental protection has made positive changes, but remains at a low level, not yet meeting the practical requirements of the increasing trend even though the province has spent regular budget spending on environmental protection activities. Fourthly: The work of inspection, inspection, supervision and law enforcement on environmental protection in the community, organizations, and enterprises are not close and effective; The implementation of ME in some industrial areas is still limited and inadequate, the work of environmental protection in industrial zones and $\mathrm{CNN}$ in general has not met the environmental protection requirements;

Fifth: The organization of overcoming environmental problems is slow, overcoming inadequate pollution consequences, such as the environmental problem caused by Fomosa Ha Tinh Co., Ltd. in the coastal area and the lagoon area of the province requested State management must focus on most of the time as well as forces to observe and resolve incidents; The work performed due to the incident has a great impact on the local environmental protection tasks.

\subsection{The Cause of the Limitations}

In general, in recent years, in the context of many environmental pressures, the province's work has also achieved remarkable results. That is thanks to the policy and decision of the leaders of Thua Thien Hue province on the role of environmental protection in socio-economic development. In addition, some shortcomings and weaknesses are due to the following reasons:

First: The rapid economic development speed operates according to the market economy. The demand for large resources increases the risk of negative impacts on the environment;

Second: The impact of the economic recession, profit targets are on top leading to limited investment in environmental protection of businesses, business establishments and the State;

Third: Awareness of environmental protection has not become a habit of residential communities, organizations and businesses.

Fourth: The law enforcement organization at all levels is not high, the implementation guidance is not good, leading to ignoring or not fully complying with the provisions of the law on environmental protection.

Fifth: Some localities have not fully and fully understood the importance of environmental protection and sustainable development, guiding the implementation and implementation of regulations on environmental pollution risks, and commitment to environmental protection. adjacent to the locality is also formal, such as allowing production activities, exploitation of natural resources, which are intermixed with pollution to take place regularly, leading to prolonged complaints. 
Sixth: The state management apparatus and organization are still inadequate; the coordination between the ministries, central branches and localities has not been regular or tight; The sense of responsibility, capacity and qualifications of officials, public servants, officials and full-time management leaders is still weak, the state loosens the management, assists violators.

Seventh: Investment in environmental management and protection has not been given adequate attention, only when there is an incident, deterioration, environmental pollution is concerned; there are no policies to encourage people, communities, and economic sectors to participate.

\section{Objectives State Management on Environment Meets the Requirements of Sustainable Development}

The country's renewal is aimed at a socialist rule-of-law state, a green economy, operating under the socialist-oriented market mechanism, implementing the process of industrialization and modernization of the country. Our Party has paid attention to the issue of environmental protection, recognized and affirmed.

Limitations and weaknesses are due to inadequate and inconsistent awareness, awareness and responsibility of many party committees, party organizations, authorities, officials, party members and people. for the immediate economic interests, sustainable development has not been attached.

The legal system, mechanisms and policies still overlap, are not clear, ineffective is not high, there are still gaps for bad actors to take advantage of for self-seeking; the handling of law violations in environmental management and protection is not strict, lacks thoroughness and deterrence.

First: Environmental management and protection should have a harmonious combination of interests between the people and the state, and management solutions include administration and control with economic activity. The foundation of the solutions is to change human perception, focus on morality, and arouse the responsibility of human to love nature.

Second: Towards transforming a new development model, according to an economic structure that countries are currently approaching, that is "Green Economy", which not only brings benefits to people, but maintains and develops development of HST.

Thirdly, for the production and business sector: reviewing and overall assessment of the electricity generation of the current development of business and production areas, from which reviewing the adjustment of development planning accordingly; Innovate and improve the effectiveness of the appraisal of strategic environmental assessment reports, assessing solar power plants to identify and forecast possible environmental impacts from investment projects in the manufacturing sector. resolutely refusing to approve projects using old and outdated technologies with a high risk of causing negative impacts on the environment; Strengthen supervision, ensuring that projects must be confirmed to complete the environmental protection works before they go into operation in accordance with regulations. State management agencies on the environment from central to local should closely supervise investment attraction in industries in accordance with the approved planning to minimize risks in the design, construction and operation process. centralized wastewater treatment system.

Fourth, the State management agency on the environment needs to develop specific plans, plans and action programs on current and future environmental protection and take sustainable development as a guideline for development. country. Fifth: strengthen inspection, examination and supervision of the implementation of the law on environmental protection, organize training courses, improve the capacity of law enforcement on environmental protection for local management agencies. Phuong; raise awareness about environmental protection. Strengthen the monitoring role of the community in the environmental protection work and build a mechanism to mobilize community participation, strengthen the propaganda and dissemination of the law for people and businesses.

\section{Solutions for the State Signature on Environment to Meet the Requirements of Sustainable Development}

Firstly: Promote propaganda and education, creating a strong change in awareness, awareness and responsibility of officials, party members, businesses, residential communities, households and all citizens. for the management and environmental protection.

Second: Consolidate and consolidate the State management organization and apparatus, clarify the functions and tasks of branches and levels from central to environmental institutions, and the environmental protection force is strong enough to carry out their duties. effective department in environmental protection and management. Strengthen the effective coordination between ministries, central agencies and localities to drastically and 
effectively inspect, inspect, supervise and promptly and effectively handle environmental pollution and incidents. environment....

Third: Review, evaluate, strictly control planning and projects on economic and social development that have negative impacts on the environment; have a mechanism to closely manage and supervise projects and programs with direct impact on the environment, to assess environmental impacts according to regulations, especially for hydropower development and mineral exploitation projects. , building industrial parks, tourist services ... Reviewing and re-evaluating socio-economic results of the projects that have been and are being implemented.

Suspension, land acquisition for wrong programs and projects causing excessive environmental pollution, or risking environmental damage, seriously affecting production activities and people's lives in the project area. ; at the same time, strictly, openly and transparently handle violating organizations and individuals, lack of responsibility in the work of investment appraisal, approval and licensing.

Fourthly: speed up the progress of investigation, measurement, development of management records, delimitation and marking of boundary markers for the zoning of EP and fieldwork to administrative units of communes, wards and towns.

Fifth: Clearly defining the management and environmental protection is the responsibility of the party committees, party organizations, authorities and heads of local organizations and agencies. The head of an agency, organization or locality must be mainly responsible for the current state of EP within the field under their management, or let organizations and individuals at their subordinate level violate the law. on environmental management and protection.

\section{Assignment of Responsibilities of Local State Management Agencies}

\subsection{Local Environmental Authorities Are Responsible for}

To assume the prime responsibility for, and coordinate with concerned agencies and units in, organizing the implementation of the environmental protection plan; annually synthesize and report to competent management agencies on the results of implementation of the following tasks: Strengthening the appraisal of EIA reports and inspecting and certifying the implementation of security works. environmental protection for the operation (post EIA) phase of projects under the management unit's scope. Report on the results of the appraisal and post EIA work annually.

\subsection{Responsibilities of the Management Board of Industrial Parks and Industrial Clusters}

Comply with the approved planning of the Industrial Park, only receive investment projects in accordance with the plan and when the industrial park meets all environmental conditions. To direct and urge industrial park infrastructure business owners under their competence to manage and complete the construction of a centralized wastewater collection and treatment system. Check and supervise the implementation of the law on environmental protection for businesses investing in industrial zones. It is required that the industrial park infrastructure business investors must fully comply with the environmental procedures before investing in construction and attracting investment.

\section{Suggestions}

\section{1) For the National Assembly and Government}

First: Continue to improve policies and laws on environmental protection in general, including systematic and synchronous urban environmental protection. Amend regulations on environmental protection in laws on environment, natural resources, taxes, investment budget, construction, science and technology, energy ... to ensure consistency, synchronization and meet the requirements of environmental protection.

Second: To focus on directing and solving urgent urban environmental problems; Orienting priority solutions for the group of big cities as well as typical cities such as coastal urban areas, mountainous urban areas to make appropriate decisions.

Third: Supplement policies to encourage and support in the management of urban CRT and urban wastewater treatment; mechanism to support the development of urban environmental service organizations. Increase the rate of spending for the cause of environmental protection to $1.5 \%$ of the total budget expenditure to meet the requirements in the new period.

2) For ministries and localities Review and propose raising Vietnam's environmental standards to the level of advanced countries in the region, proactively responding to climate change, strengthen natural resource management, protect the environment, and review facilities capable of causing heavy pollution nationwide, at the same time conducting a comprehensive inspection of all aspects from investment policy to environmental impact assessment, post-examination, 
inspection and examination; including state management at all levels to the execution of businesses; actively reforming administration, building a streamlined management apparatus at all levels; professional and effective; applying advanced technology in natural resources and environment management; perfecting the environmental monitoring system nationwide, in the direction of using automatic monitoring technology, connecting information via the network; Extensive environmental integration with other countries around the world, especially climate change. Together with world leaders, through the Millennium Development Goals, continue to learn from experience, as well as participate in the development of institutions related to resource management, especially issues of environment, transnational water resources. At the same time, take advantage of converting challenges into development opportunities in Vietnam, building a green economic model, green growth.

In summary: With the characteristics and role of the environment, the State should have immediate and long-term supportive policies in the overall state management activities for environmental protection; have high level of sanctions and strictly handle violations of environmental laws. Environmental management and protection is the cause of the entire Party, the entire army, and requires international cooperation from the countries in the region.

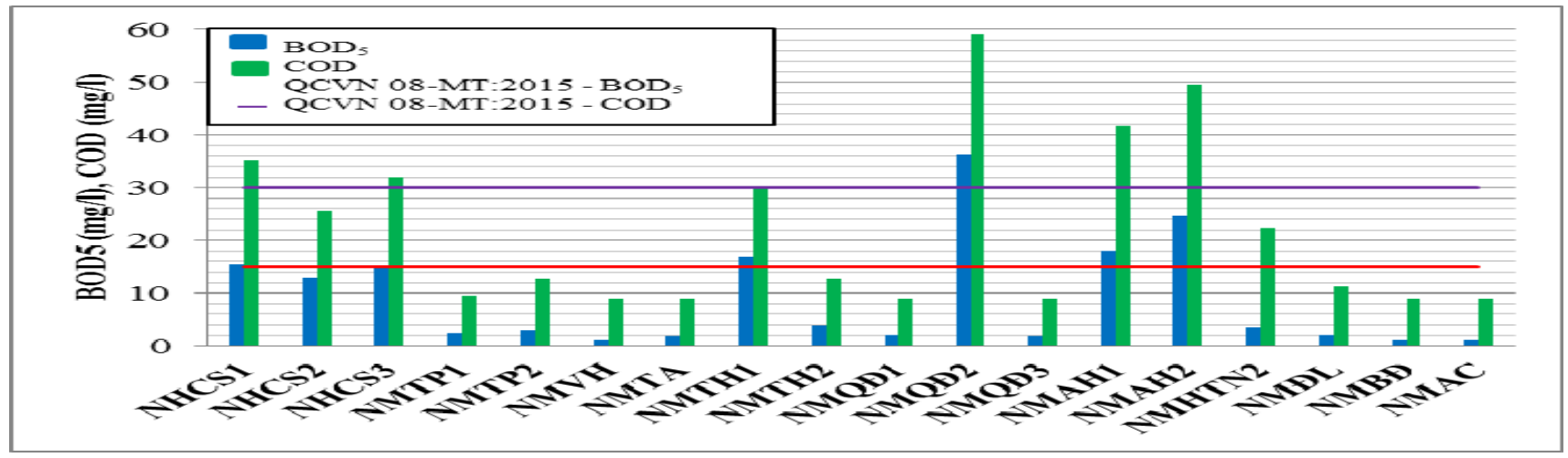

Figure 1. Concentration of suspended solids (TSS) in wastewater of some facilities in industrial complexes

Source: General International Exchange Center 2018

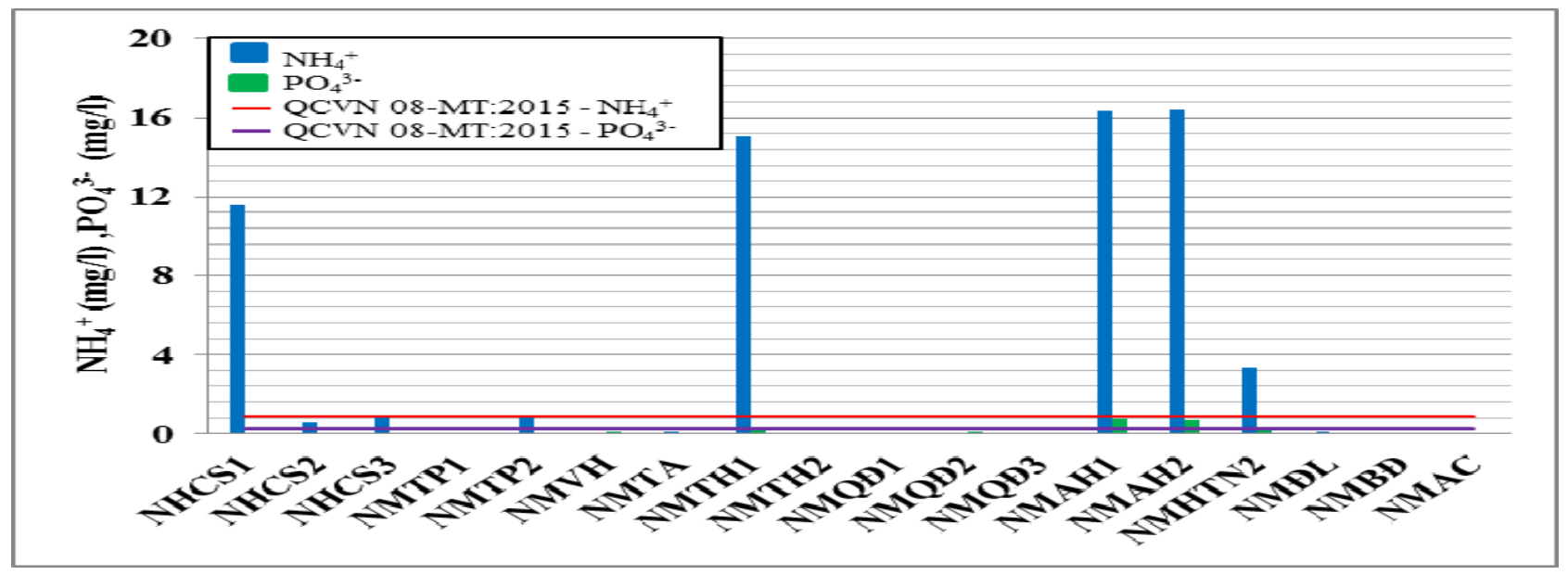

Figure 2. BOD5, COD concentrations in rivers, lakes, bald and ditches passing through industrial complexes Source: General International Exchange Center 2018 


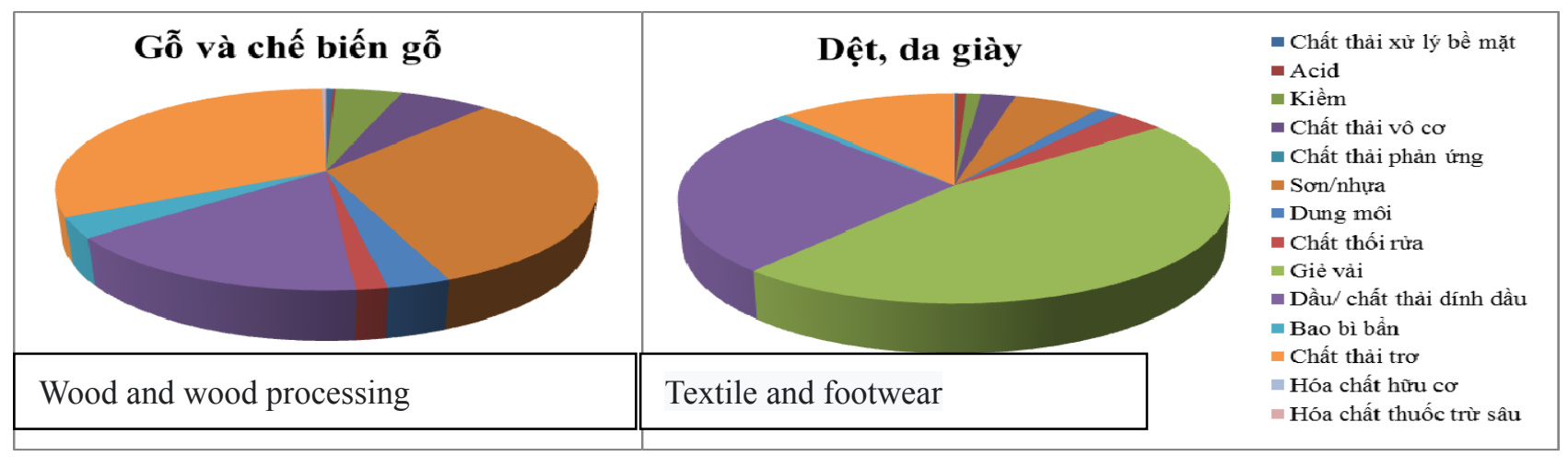

Figure 3. Content of parameters in the ambient air at the working positions of some factories in industrial complex

Source: General International Exchange Center 2018

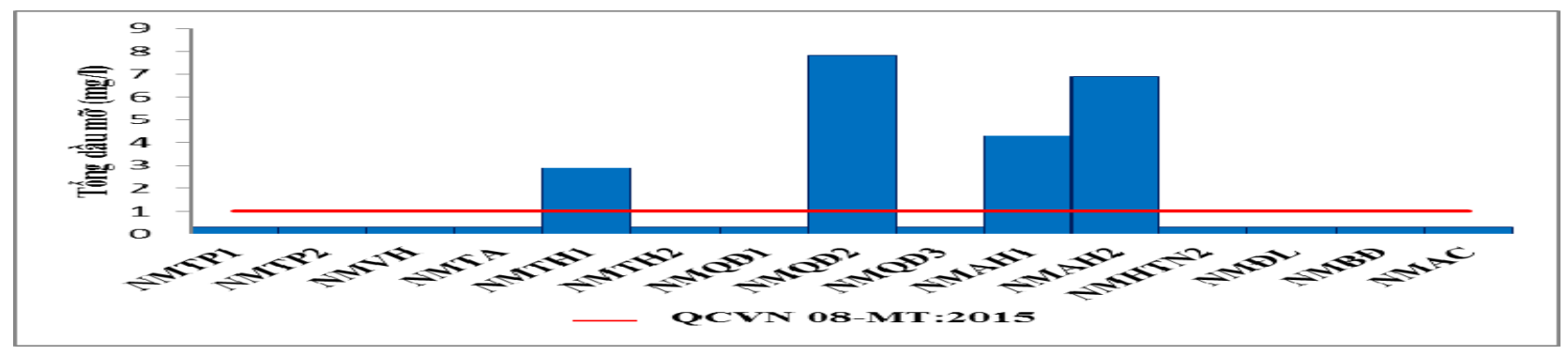

Figure 4. Concentration of suspended solids (TSS) in wastewater of some facilities in industrial complexes Source: International payment compiled

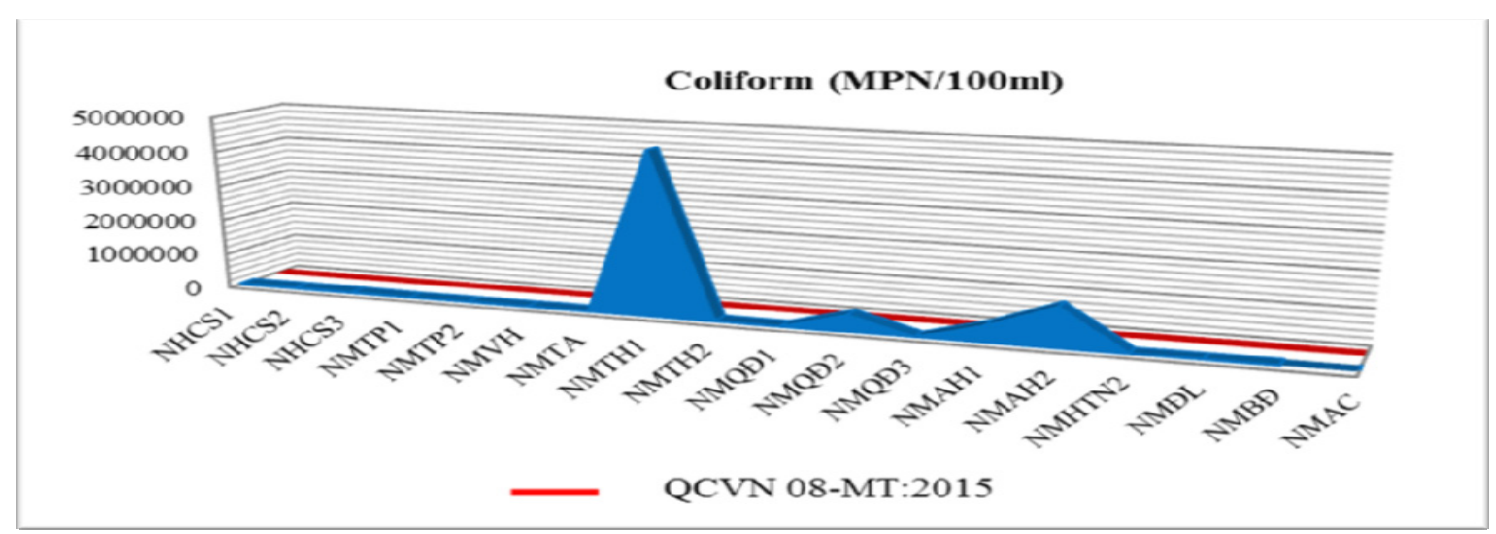

Figure 5. Oil and grease content in rivers, lakes, baldness and ditches passing through industrial complexes Source: General International Exchange Center 2018 


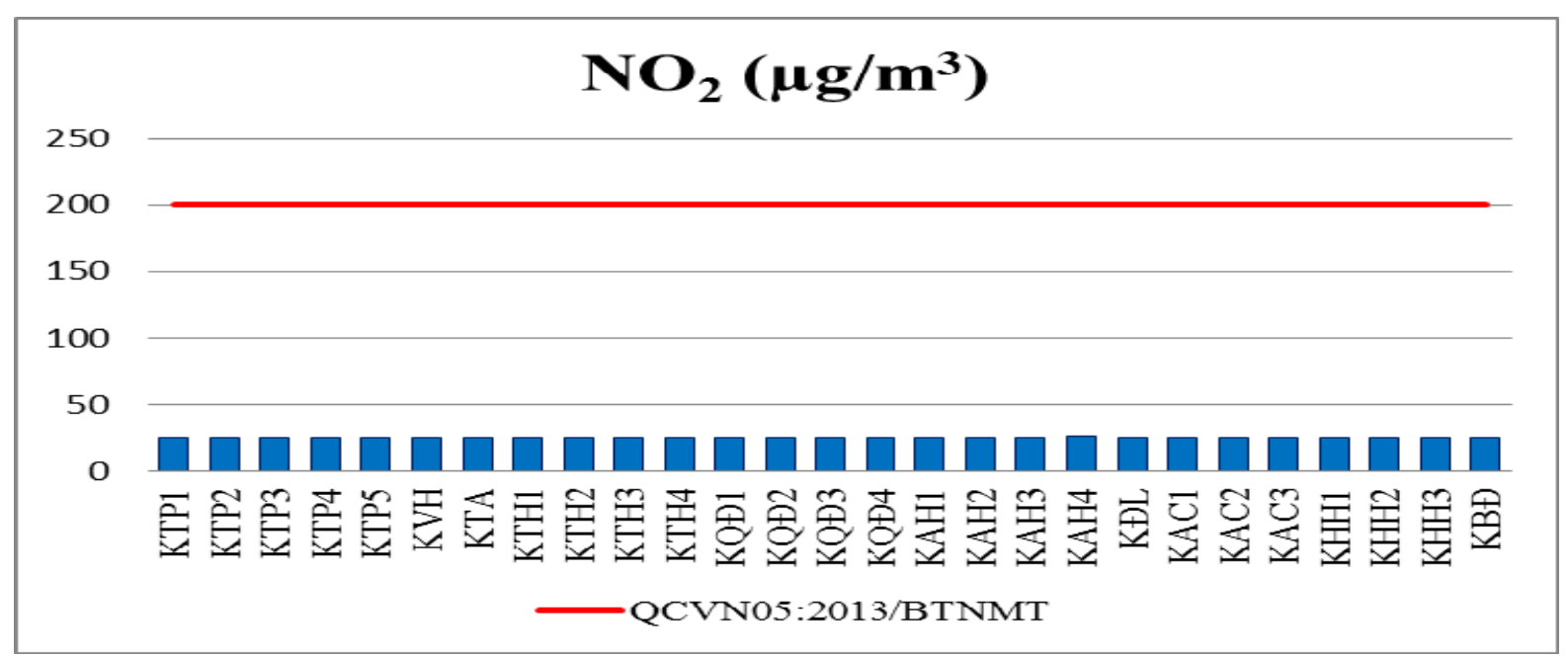

Figure 6. $\mathrm{CO}$ concentration in the air in Ics

Source: General International Exchange Center 2018

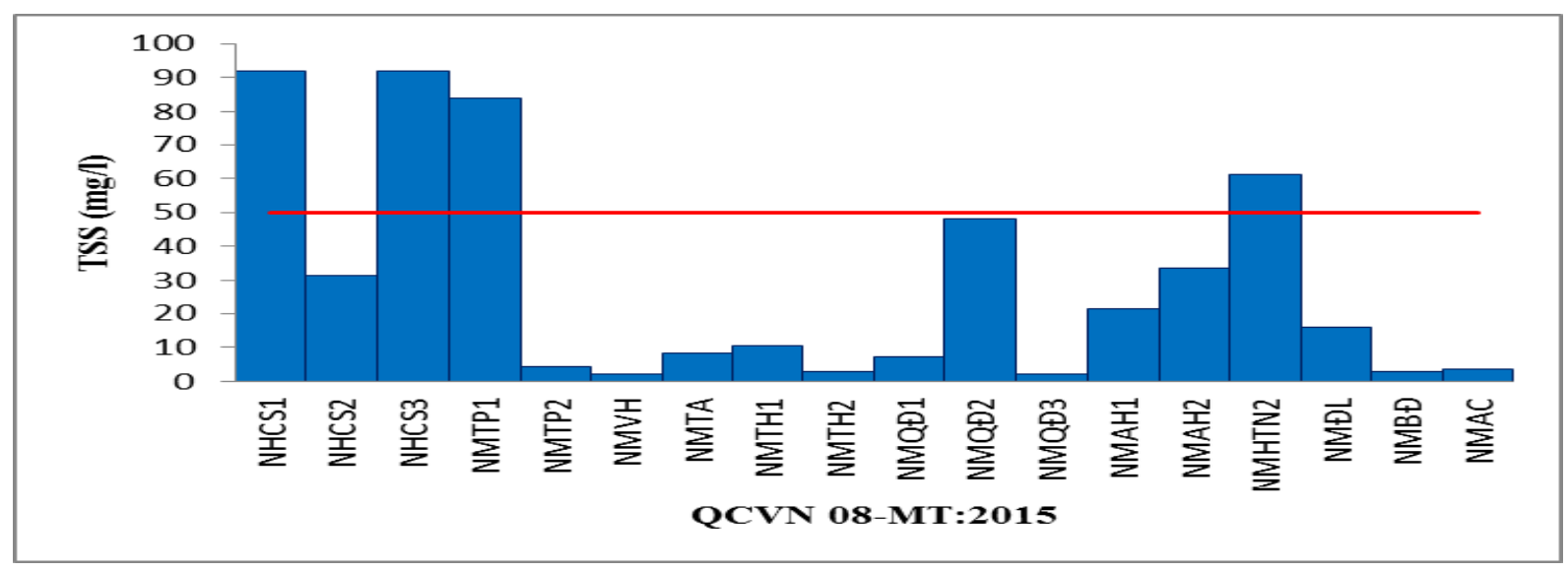

Figure 7. Proportion of hazardous waste composition of some manufacturing industries

Source: General International Exchange Center 2018

Table 1. List of industrial clusters in Thua Thien Hue province

\begin{tabular}{|c|c|c|c|}
\hline No & Industrial clusters & Area according to detailed planning (m2) & Rented area $(\mathrm{m} 2)$ \\
\hline 01 & An Hòa & 480.000 & 212.866 \\
\hline 02 & Thủy Phương & 750.000 & 445.500 \\
\hline 03 & Tứ Hạ & 550.000 & 271.800 \\
\hline 04 & Bình Điền & 300.000 & - \\
\hline 05 & Bắc An Gia & 165.000 & 12.290 \\
\hline 06 & Điền Lộc & 300.000 & - \\
\hline 07 & $\mathrm{ACo}$ & 302.400 & 20.000 \\
\hline 08 & Hương Hòa & 68.400 & 20.000 \\
\hline 09 & Thuận An & 145.000 & - \\
\hline 10 & Vinh Hưng & 200.000 & - \\
\hline
\end{tabular}

Source: Statistical report of Thua Thien Hue province 2018 
Table 2. Characteristics of wastewater components of some industries

\begin{tabular}{|c|c|c|}
\hline No & Industry & Pollutant \\
\hline 01 & Mechanical & $\mathrm{COD}, \mathrm{SS}, \mathrm{CN}^{-}, \mathrm{Cr}, \mathrm{Ni}, \mathrm{N}, \mathrm{P}$ \\
\hline 02 & Weaving and dyeing & SS, BOD, heavy metals, grease, color, turbidity \\
\hline 03 & Chemical fertilizers & $\begin{array}{l}\mathrm{pH} \text {, độ axit, } \mathrm{F}, \mathrm{N}, \mathrm{P} \text {, heavy metals, grease, color, turbidity } \\
\text { heavy metals, grease, color, turbidity heavy metals, grease, } \\
\text { color, turbidity }\end{array}$ \\
\hline 04 & Producing chemical fertilizers & $\mathrm{NH}_{4}^{+}, \mathrm{NO}_{3}^{-}$, urê, $\mathrm{pH}$, organic compounds \\
\hline 05 & Paper production & $\mathrm{pH}, \mathrm{TSS}, \mathrm{BOD}_{5}, \mathrm{COD}$ \\
\hline 06 & Bottled water production & $\mathrm{BOD}_{5}, \mathrm{COD}, \mathrm{TSS}$ \\
\hline 07 & Confectionery production & $\mathrm{BOD}_{5}, \mathrm{COD}, \mathrm{TSS}, \mathrm{pH}, \mathrm{N}, \mathrm{P}$, Coliform \\
\hline 08 & Produce plastic & $\mathrm{BOD}_{5}, \mathrm{COD}, \mathrm{TSS}, \mathrm{pH}, \mathrm{N}, \mathrm{P}$ \\
\hline 09 & Printing & $\mathrm{BOD}_{5}, \mathrm{COD}, \mathrm{TSS}, \mathrm{pH}, \mathrm{N}, \mathrm{P}$, Coliform \\
\hline 10 & Producing shoes & $\mathrm{BOD}_{5}, \mathrm{COD}, \mathrm{SS}$, dầu mỡ, $\mathrm{pH}, \mathrm{Màu}, \mathrm{SO}_{4}{ }^{2-}, \mathrm{Cr}(\mathrm{VI}), \mathrm{N}, \mathrm{P}, \mathrm{Cl}^{-}$ \\
\hline 11 & Electronic components production & $\mathrm{pH}$, dầu mỡ, $\mathrm{BOD}_{5}, \mathrm{COD}, \mathrm{TSS}$ \\
\hline 12 & Concrete production & pH, dầu mỡ, $\mathrm{BOD}_{5}, \mathrm{COD}, \mathrm{TSS}$ \\
\hline 13 & Production of plastic packaging & $\mathrm{pH}, \mathrm{N}, \mathrm{P}, \mathrm{BOD}_{5}, \mathrm{COD}, \mathrm{TSS}$ \\
\hline 14 & Process the wood & $\mathrm{pH}, \mathrm{N}, \mathrm{P}, \mathrm{BOD}_{5}, \mathrm{COD}, \mathrm{TSS}, \mathrm{SO}_{4}^{-}$ \\
\hline 15 & Processing fish sauce & $\begin{array}{l}\mathrm{pH} \text {, màu, Tổng } \mathrm{N} \text {, tổng } \mathrm{P}, \mathrm{BOD}_{5}, \mathrm{COD} \text {, TSS, độ đục, độ muối, } \\
\text { độ màu, dầu mỡ }\end{array}$ \\
\hline 16 & Construction stone processing & $\mathrm{pH}, \mathrm{COD}, \mathrm{BOD}_{5}, \mathrm{TSS}$ \\
\hline
\end{tabular}

Source: International payment compiled

Table 3. Locations of wastewater monitoring points in some facilities of industrial complexes

\begin{tabular}{|c|c|c|c|}
\hline No & $\begin{array}{l}\text { Ký hiệu } \\
\text { Symbol }\end{array}$ & (Observation location) & $\begin{array}{l}\text { Coordinates VN } 2000(\mathrm{~m}) \\
(\text { KTT } 1070 \text { zones } 30)\end{array}$ \\
\hline \multirow{2}{*}{01} & \multirow{2}{*}{ NT1 } & Sample of wastewater collected at the last tank of Thanh Loi & $\mathrm{X}: 1.824 .158$ \\
\hline & & Multi-Sector Investment Co., Ltd. - auto facility & Y: 558.118 \\
\hline \multirow{2}{*}{02} & \multirow{2}{*}{ NT2 } & At the connection point of wastewater and the common drainage & $X: 1.823 .603$ \\
\hline & & system of Minh Phat Trading and Transport Company Limited & Y: 558.293 \\
\hline \multirow{2}{*}{03} & \multirow{2}{*}{ NT3 } & Wastewater sample taken at the manhole of Hue Food Industry & $\mathrm{X}: 1.823 .494$ \\
\hline & & Joint Stock Company & Y: 558.301 \\
\hline \multirow{2}{*}{04} & \multirow{2}{*}{ NT4 } & Wastewater sample collected at manhole of Thien Huong & $\mathrm{X}: 1.823 .632$ \\
\hline & & Company Limited & Y: 558.174 \\
\hline \multirow{2}{*}{05} & \multirow{2}{*}{ NT5 } & At the connection point of wastewater and the common drainage & $\mathrm{X}: 1.823 .601$ \\
\hline & & system of Vietnam Japan Import and Export Company Limited & Y: 558.471 \\
\hline 06 & NT6 & $\begin{array}{l}\text { Sample of wastewater taken from the manhole connected to the } \\
\text { wastewater collection system of IC at Hello International Vietnam } \\
\text { Joint Stock Company }\end{array}$ & $\begin{array}{l}X: 1.823 .752 \\
Y: 558.471\end{array}$ \\
\hline \multirow{2}{*}{07} & \multirow{2}{*}{ NT7 } & Waste water sample taken at the manhole of Thien An Phuc & $\mathrm{X}: 1.823 .820$ \\
\hline & & Textile Joint Stock Company & Y: 558.058 \\
\hline \multirow{2}{*}{08} & \multirow{2}{*}{ NT8 } & Wastewater sample collected at manhole of Phuc Hung & $\mathrm{X}: 1.823 .801$ \\
\hline & & Production and Trading Co., Ltd. & Y: 558.237 \\
\hline
\end{tabular}




\begin{tabular}{|c|c|c|c|}
\hline No & $\begin{array}{l}\text { Ký hiệu } \\
\text { Symbol }\end{array}$ & (Observation location) & $\begin{array}{l}\text { Coordinates VN } 2000(\mathrm{~m}) \\
\text { (KTT } 1070 \text { zones } 30)\end{array}$ \\
\hline \multirow{2}{*}{09} & \multirow{2}{*}{ NT9 } & The wastewater sample is collected at the manhole of Loc Tho & X: 1.823 .983 \\
\hline & & Production, Trade and Service Company Limited & Y: 558.157 \\
\hline \multirow{2}{*}{10} & \multirow{2}{*}{ NT10 } & Wastewater sample collected at manhole of Huy Quan Company & $\mathrm{X}: 1.824 .038$ \\
\hline & & Limited) & Y: 558.309 \\
\hline \multirow{2}{*}{11} & \multirow{2}{*}{ NT11 } & Sample of wastewater collected from the manhole of Hue Urban & $\mathrm{X}: 1.824 .123$ \\
\hline & & Construction and Environment Joint Stock Company & Y: 558.240 \\
\hline \multirow{2}{*}{12} & \multirow{2}{*}{ NT12 } & Wastewater samples collected at manholes of SDC Construction, & $\mathrm{X}: 1.824 .173$ \\
\hline & & Manufacturing and Trading Co., Ltd & Y: 558.347 \\
\hline \multirow{2}{*}{13} & \multirow{2}{*}{ NT13 } & Wastewater sample taken at the manhole of Thien An Phat Textile & $\mathrm{X}: 1.824 .038$ \\
\hline & & and Garment Joint Stock Company - wash facility & Y: 557.820 \\
\hline \multirow{2}{*}{14} & \multirow{2}{*}{ NT14 } & Wastewater sample collected at manhole of San Hien & $\mathrm{X}: 1.823 .955$ \\
\hline & & Transportation Company Limited & Y: 557.893 \\
\hline \multirow{2}{*}{15} & \multirow{2}{*}{ NT15 } & Wastewater samples collected from manholes of Tam Tin & X: 1.823 .695 \\
\hline & & traditional private enterprise & Y: 558.090 \\
\hline \multirow{2}{*}{16} & \multirow{2}{*}{ NT16 } & Wastewater sample collected from manhole of Duy Tran Printing & X: 1.823 .907 \\
\hline & & Company Limited & Y: 558.090 \\
\hline \multirow{2}{*}{17} & \multirow{2}{*}{ NT17 } & Wastewater sample collected at manhole of Dang Tuan & $\mathrm{X}: 1.823 .907$ \\
\hline & & Production, Trade and Service Co., Ltd. & Y: 558.254 \\
\hline \multirow{2}{*}{18} & \multirow{2}{*}{ NT18 } & Wastewater samples collected from manholes of the Huetronics & $\mathrm{X}: 1.823 .770$ \\
\hline & & Corporation & Y: 558.337 \\
\hline \multirow{2}{*}{19} & \multirow{2}{*}{ NT19 } & Wastewater sample collected at the manhole of Dai Viet Export & $\mathrm{X}: 1.824 .041$ \\
\hline & & Garment Joint Stock Company & Y: 557.965 \\
\hline \multirow{2}{*}{20} & \multirow{2}{*}{ NT20 } & At the connection point of wastewater and the common drainage & X: 1.823 .894 \\
\hline & & system of Hue Leather and Footwear Joint Stock Company & Y: 558.149 \\
\hline \multirow[b]{2}{*}{21} & \multirow[b]{2}{*}{ NT21 } & Sample of wastewater collected at manhole of Thien An Phat & $\mathrm{X}: 1.824 .135$ \\
\hline & & $\begin{array}{l}\text { Textile and Investment Joint Stock Company - garment } \\
\text { establishment }\end{array}$ & Y: 557.853 \\
\hline \multirow{2}{*}{22} & \multirow{2}{*}{ NT22 } & At the connection point of the wastewater and drainage system of & $\mathrm{X}: 1.823 .922$ \\
\hline & & Phat Dat Company Limited & Y: 558.388 \\
\hline \multirow{2}{*}{23} & \multirow{2}{*}{ NT23 } & Wastewater sample taken at the manhole of Hue onuments & $\mathrm{X}: 1.823 .881$ \\
\hline & & Reclamation Joint Stock Company & Y: 558.544 \\
\hline 24 & NT24 & Wastewater camnle at Kicora Garment Factorv & $\mathrm{X}: 1.785 .814$ \\
\hline 24 & $1 \mathrm{~N} 124$ & Wastewaler sampie at Nisora Uamment ractory & Y: 574.280 \\
\hline 25 & NT25 & Wastewater sample at plastic recycling production facility in Bac & $\mathrm{X}: 1.834 .285$ \\
\hline $2 \mathrm{~J}$ & 10120 & An Gia industrial cluster & Y: 554.193 \\
\hline
\end{tabular}

Source: Thua Thien Hue Environment Administration 2017 
Table 4. Solid waste composition of some typical industries

\begin{tabular}{|c|c|c|}
\hline No & Industry & Solid waste composition \\
\hline 1 & Textile, dyeing and garment & Fabric fibers, rags, textile wastewater sludge, chemical packaging, .. \\
\hline 2 & Tanning & Fur, leather, grease, waste water treatment mud ... \\
\hline 3 & Paper and pulp & Pulp, scrap paper, activated sludge after wastewater treatment, lignin, .. \\
\hline \multirow[t]{4}{*}{4} & Chemistry & Residue after filtration, sedimentation, molten S, plastic can, packa \\
\hline & -Producing sulfuric acid) & Red mud \\
\hline & $-\mathrm{Al}(\mathrm{OH})_{3}$ & Packaging, sludge from WWTP) \\
\hline & .- Pesticides, antiseptics & \\
\hline \multirow[t]{6}{*}{5} & -Food Processi & Activated carbon, filter aid, organic waste dump ... \\
\hline & -Monosodium glutamate, nstant & Shrimp shells, crabs, fish intestines, seafood waste, packaging, ... \\
\hline & noodles. Seafood & Packaging: paper, nylon, iron, foil ... \\
\hline & - processing Mil & Cashew nut shell, pod, fruit seed) \\
\hline & - Cashew, - Fruit juice & Molasses molasses, sludge mixed with activated carbon \\
\hline & - Street, Cigarette & Dust from yarn cutting, cigarette cuttin \\
\hline 6 & Breed & Feces, carcasses of cattle, poultry, and food are scattered \\
\hline 7 & $\begin{array}{l}\text { Metal casting and processing } \\
\text { industry }\end{array}$ & \\
\hline 8 & Electronic & Electronic circuit boards, solder lag, packaging, .. \\
\hline 9 & Building materials & Packaging, broken tiles, debris \\
\hline 10 & Process the wood & Wood chips, sawdust, shavings, \\
\hline 11 & Petroleum & Sediment from storage tanks \\
\hline
\end{tabular}

Source: Industrial waste treatment technique, Nguyen Van Phuoc, National University Publishing House. Ho Chi Minh City, 2015 
Table 5. Typical pollutants of each manufacturing industry

\begin{tabular}{|c|c|c|}
\hline No & Manufacturing & Typical pollutants \\
\hline 01 & $\begin{array}{l}\text { Industries with boilers, dryers or fuel-fired } \\
\text { generators }\end{array}$ & Bụi, $\mathrm{SO}_{\mathrm{x}}, \mathrm{NO}_{\mathrm{x}}, \mathrm{CO}_{\mathrm{x}}$, hydrocacbon, aldehyt... \\
\hline \multirow[t]{3}{*}{02} & Food Processing & Dust, smell \\
\hline & - Producing ice & $\mathrm{NH}_{3}$ \\
\hline & - Processing cashew nuts & Dust, odors, phenol derivatives \\
\hline 03 & Cigarette & Dust, odor, nicotine \\
\hline 04 & Weaving and dyeing & Dust, organic compounds \\
\hline 05 & Pape & Dust, bad smell \\
\hline \multirow[t]{7}{*}{06} & Chemical production & $-\mathrm{SO}_{\mathrm{x}}$ \\
\hline & - Axit sunfuaric & - Bụi, HF, $\mathrm{SiF}_{4}$ \\
\hline & - Superphotphat & $-\mathrm{NH}_{3}$ \\
\hline & - Amoniac & - Dust, organic compounds (solvents) \\
\hline & - (Glue, paint, varnish & - Dust, alkali \\
\hline & - Soap, washing powde & - Hydrocacbon, bụi, $\mathrm{CO}_{\mathrm{x}}, \mathrm{SO}_{\mathrm{x}}, \mathrm{NO}_{\mathrm{x}}$ \\
\hline & - Oil Filter & \\
\hline 07 & Porcelain, glass, building materials & Bụi, $\mathrm{CO}_{x}, \mathrm{HF}, \mathrm{SiF}_{4}$ \\
\hline 08 & Metallurgy, foundry urnace & Bụi, $\mathrm{SO}_{2}, \mathrm{CO}_{\mathrm{x}}$ chì \\
\hline 09 & Plastic, rubber, plastic & Dust, bad smell \\
\hline 10 & Pesticides & Dust, odors, solvents \\
\hline 11 & Tanning & Bad smell \\
\hline 12 & Packaging & Bad smell \\
\hline 13 & Traffic emissions & $\mathrm{Pb}, \mathrm{SO}_{\mathrm{x}}, \mathrm{NO}_{\mathrm{x}}, \mathrm{CO}_{\mathrm{x}}$ \\
\hline 14 & Domestic waste gas & $\mathrm{CO}_{\mathrm{x}}$ \\
\hline
\end{tabular}

Source: Industrial waste treatment technique, Nguyen Van Phuoc, National University Publishing House. Ho Chi Minh City, 2015. 
Table 6. Solid waste composition of some typical industries

\begin{tabular}{lll}
\hline No & Industry & \multicolumn{1}{c}{ Solid waste composition } \\
\hline 1 & Textile, dyeing and garment) & \multicolumn{1}{c}{ Fabric fibers, rags, textile wastewater sludge, chemical packaging, ... } \\
2 & Thuộc da (Tanning) & Fur, leather, grease, waste water treatment mud ... \\
3 & $\begin{array}{l}\text { Giấy và bột giấy (Paper and } \\
\text { pulp) }\end{array}$ & Pulp, scrap paper, activated sludge after wastewater treatment, lignin, .. \\
4 & Chemistry) & Residue after filtration, sedimentation, molten S, plastic cans, packaging, ... \\
& - Producing sulfuric acid & Red mud \\
& - Al(OH) $)_{3, \text { Pesticides, ntiseptics }}$ & Packaging, sludge from WWTP \\
5 & Food Processing & Activated carbon, filter aid, organic waste dump ... \\
& - Monosodium glutamate, nstant & Shrimp shells, crabs, fish intestines, seafood waste, packaging \\
& noodles & Packaging: paper, plastic, iron, foil ...0 \\
& - Seafood processing & Cashew nut shell \\
& - Milk & Fruit pods and seeds \\
& -Cashew, Fruit juice, Street, & Molasses molasses, sludge mixed with activated carbon \\
& Cigarette & Dust from yarn cutting, cigarette cutting \\
6 & Breed & Feces, carcasses of cattle, poultry, and food are scattered \\
7 & Metal casting and processing & Iron scrap, metal slag, ... \\
& industry & \\
8 & Electronic & Electronic circuit boards, solder slag, packaging, ... \\
9 & Building materials & Packaging, broken tiles, debris ... \\
10 & Process the wood & Wood chips, sawdust, shavings, \\
\hline & Petroleum & (Sediment from storage tanks \\
\hline
\end{tabular}

Source: Industrial waste treatment technique, Nguyen Van Phuoc, National University Publishing House. Ho Chi Minh City, 2015.

\section{References}

Assoc. Prof. Dr. Nguyen The Chinh (editor), Economics and Environmental Management, Statistical Publishing House, 2003.

Bui, D. H. (2014). "Legal institutions on environmental protection in Vietnam", topic "Completing legal institutions of the socialist-oriented market economy in Vietnam in the context of State construction. Rule of Law and International Integration". State Institute and Law.

Circular No. 15/2017 / TT-BCT of the Ministry of Industry and Trade regulating and guiding the implementation of some contents of the Government's Decree No. 68/2017 / ND-CP dated May 25, 2017 on management industrial structure development.

Circular No. 31/2016 / TT-BTNMT of the Ministry of Natural Resources and Environment on industrial zone environmental protection, concentrated business and service areas, trade villages and production, business and service Trung.

Circular No. 35/2015 / TT-BTNMT dated June 30, 2015 on environmental protection of EZs, IZs, EPZs, and $\mathrm{KCNCs}$, which provide specific regulations related to environmental protection in industrial zones.

Decision No. 07/2017/QD-UBND dated February 10, 2017 on the promulgating of regulations on environmental protection in livestock and poultry husbandry activities on farm and industrial scale in Thua Thien Hue province.

Decision No. 1169 / QD-TTg dated August 10, 2017 of the Prime Minister on approving the Project of strengthening the organizational apparatus and capacity building for environmental management staff from China. nursing to the locality in the period of 2017 - 2020, with a vision to 2030. 
Decision No. 69/2017 / QD-UBND dated 25/8/2017 providing for the construction and operation of environmental biological indicator lakes in the management of industrial wastewater in Thua Thien Hue province.

Decree 155 / ND-CP dated November 18, 2016 of the Government providing for the sanctioning of administrative violations in the field of environmental protection.

Decree No. 120/2016 / ND-CP dated August 23, 2016 of the Government detailing and guiding the implementation of a number of articles of the Law on fees and charges.

Decree No. 154 / ND-CP dated November 16, 2016 of the Government on environmental protection fees for wastewater.

Decree No. 19/2015 / ND-CP, dated February 14, 2015 of the Government detailing a number of articles of the Law on Environmental Protection.

Decree No. 38/2015 / ND-CP of the Government on waste and scrap management.

Decree No. 68/2017 / ND-CP of the Government on management and development of industrial clusters.

Directive No. 12 / CT-BCT of the Ministry of Industry and Trade on the implementation of Decree No. 68/2017 / ND-CP dated May 25, 2017 of the Government on the management and development of industrial complexes.

Directive No. 25 / CT-TTg dated 31/8/2016 of the Prime Minister on a number of urgent tasks and solutions to environmental protection, strengthening the work of state management and compliance with the above law on environmental protection. Thua Thien Hue province.

Directive No. 28 / CT-UBND dated December 2, 2016 on strengthening the state management and compliance with the law on environmental protection in Thua Thien Hue province.

Doan Cong Khanh, Ministry of Industry and Trade on green growth, low carbon economic development in China and suggestions for Vietnam, April 17, 2019 (VNA).

Green economy - General development trend of the world, Industry and Trade magazine on environment, August 20, 2013.

International Organizations for the Environment (Ministry of Natural Resources and Environment).

Law on Environment Protection 2014 and Law on Environment Protection 2020.

Law on local government organization 2015.

Law on Marine and Island Natural Resources and Environment in 2015.

National environmental status report in 2016, dated 20/7/2017 by the Ministry of Natural Resources and Environment.

Phung Van Hien, People's Public Security Review (September 2019) p. 44-47, State management of the environment in a socialist-oriented market economy.

Phung Van Hien, State Management Journal, National Academy of Public Administration (May 2018), p. 79- 34. Economy and environment - Solutions for sustainable development.

Phung, V. H., \& Phung, K. L. (2020). Forest Management Meeting the Requirements for Sustainable, Development in Vietnam. Public Administration Research, 9(2). https://doi.org/10.5539/par.v9n2p15

Plan No. 199 / KH-UBND dated October 5, 2017 of the People's Committee of Thua Thien Hue province on solving environmental issues in the process of international economic integration, period 2017-2022.

Plan No. 20 / KH-UBND dated January 26, 2016 of the People's Committee of Thua Thien Hue Province on the implementation of the Government's Resolution No. 35 / NQ-CP dated March 18, 2013 on some urgent issues in environmental protection.

Plan No. 200 / KH-UBND dated October 5, 2017 of the People's Committee of Thua Thien Hue province on mobilizing community resources, taking advantage of the support and funding of international organizations in environmental protection and response to climate change in the period of $2017-2022$.

Project on solid waste collection and treatment in Thua Thien Hue province to 2015, with an orientation to 2020 .

Report No. 296 / BC-CP dated 15/02/2018 of the Government on results of international economic integration since Vietnam's accession to WTO, page 69. 
Resolution No. 36-NQ / TW dated October 22, 2018, the eighth meeting of the 12th Party Central Committee on Vietnam's Strategy for Sustainable Marine Economic Development to 2030, with a Vision to year 2045.

Summary report on environmental management and protection from 2013 to 2018 and directions and tasks of environmental protection in the coming time of Thua Thien Hue province.

Vietnam attaches great importance to international and regional cooperation to join hands in solving challenges on water resources, the 8th World Water Forum, March 25, 2018.

\section{Copyrights}

Copyright for this article is retained by the author(s), with first publication rights granted to the journal.

This is an open-access article distributed under the terms and conditions of the Creative Commons Attribution license (http://creativecommons.org/licenses/by/4.0/). 